\title{
満族の頭顔部および歯列弓の形態に関する研究
}

\author{
久保博英 \\ 九州歯科大学口腔解剖学第一講座（指導：小林 繁教授)
}

平成 9 年 2 月 26 日受理

\section{A Study on Anthropometric Measurement of Head and Face, and Morphology of Dental Arch on Manchu Tribe \\ Hirohide Kubo}

First Department of Oral Anatomy (Director: Prof. Shigeru Kobayashi) Kyushu Dental College, Kitakyushu, Japan

In August and September of 1995 the author conducted an anthropometric examination of the head and face, and measurement of the dental arch on Manchu tribe (82 males and 83 females), inhabitants of Feng Cheng City. Furthermore, the correlations between the measurements of head and face, and those of dental arches and palate height were studied. The results obtained in this study were as follows:

1) Head length: The mean value for the male is $175.6 \mathrm{~mm}$ and for the female $168.4 \mathrm{~mm}$, both of the Short Type.

2) Head breadth: The mean value for the male is $156.3 \mathrm{~mm}$ and for the female $151.3 \mathrm{~mm}$, both of the Wide Type.

3 ) Bizygomatic breadth: The mean value for the male is $139.9 \mathrm{~mm}$ and for the female $134.1 \mathrm{~mm}$, both of the Middle Type.

4) Morphological facial hight: The mean value for the male is $124.5 \mathrm{~mm}$ and for the female $118.5 \mathrm{~mm}$, both of the High Type.

5 ) The head-type of the Manchu tribe is of the Hyperbrachycephalic Type and the facetype Leptoprosopic Type.

6 ) Correlation: For male no significant correlation was found between bizygomatic breadth and upper dental arch breadth or between bigonial breadth and lower dental arch breadth. But significant positive correlation was shown in the head height and palate height. In female, no significant correlation was found between morphological face height and palate height or between bigonial breadth and lower dental arch breadth. But significant positive correlation was shown in the head breadth and upper dental arch breadth.

Key words: Manchu tribe/Anthropometric measurement/Dental arch 


\section{緒言}

中国東北部には漢族，満族，回族，蒙古族，朝鮮族な ぞ人口百万人以上の比較的多数の民族之, 達呼爾族, 索 倫族，鄂倫春族，錫伯族，赫哲族などの少数民族が居住 する”。これらの諸民族のうち，先住民族は赫哲族であ り, 通古斯系 (Tungus) の満族, 達呼爾族, 索倫族, 鄂倫春族，錫伯族と蒙古系（Mongols）の諸族が侵入 し，後に漢族および朝鮮族が多数を移住した"1. 同地区 における人類学的研究には昭和初期, 満州国の建国のの ち，今村ら $(1939)^{13}$, 横尾 $(1939)^{2)}$, 矢吹 $(1942)^{3)}$, 荷 宮 $(1948)^{4)}$ の報告がみられるが，その後約 50 年間は報 告をみない，そこで現時点での同地区の各民族の頭顔部 おょび歯列弓の形態を把握するために，伊東ら $(1996)^{5)}$ は漢民族の形態について調查した，著者は満 族の頭顔部の生体計測之歯列弓の計測により，現状の把 握と先人との比較を行った，㐘列弓に関しては，人類学 的見地加ら多くの研究をみるものの, 頭顔部之歯列弓之 の相関関係についての研究は, 大島 $(1936)^{6)}$, 深沢 $(1941)^{7)}$, 酒井 $(1955)^{87}$, 浜田 $(1965)^{9)}$, 南 $(1976)^{10)}$, 加藤 $(1972)^{11)}$, 大森ら $(1985)^{12}$, 内出 $(1987)^{132}$, 毛利

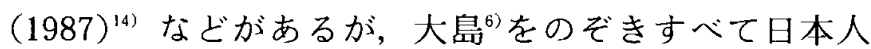
や台湾人を対象に行ったものである．本研究では民族 差，地域差をより明確にするため，頭顔部之歯列弓との 相関関係を含めて検討した。

\section{調查資料ならびに方法}

調査資料は，中華人民共和国遼寧省の東部に位置する 鳳城市の満族中級学校に通学する 16 歳〜19 歳の満族, 男性 82 名，女性 83 名である.

資料の採得は，現地にて頭顔部の生体計測を行なうと とあに，アルギン酸印象材による上下顎の印象採得の 後, 超硬石膏により模型を作製した。

1. 頭顔部の計测計测項日は, 頭最大長, 頭最大幅, 頭耳高，頬骨弓幅，下顎角幅，容貌顔面高，形態顔面高 である．下顎角幅は日本学術会議生体計測班の協定に従 い，その他は全て Martin（1957) $)^{15)}$ に従った。なお形 態顔面高の上位点はNasion をとった。これらの計測值 より頭長幅指数, 頭長高指数, 頭幅高指数, 横頭顔指 数, 容貌顔面指数, 形態顔面指数, 下顎指数および鉛直 䫓顔指数を算出した。形態分類は Lebzelter-Saller ${ }^{15)}$ お よび Martin-Saller ${ }^{(5)}$ に従った。

2 . 歯列局の計測

蒾列户の計測項月は，1）前歯列弓長，2）前歯列弓
幅, 3 ) 後菌列弓長, 4 ) 後歯列弓幅, 5 ) 歯列弓長, 6）歯列弓幅，7）日蓋高とした。1）～4）は山浦

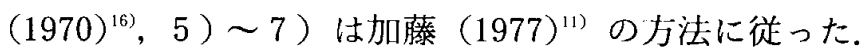
計測には $1 / 100 \mathrm{~mm}$ デジタル表示のノギスを使用し た。これらの計測值より, 前雨列弓長幅指数「2)/ 1)」, 後歯列弓長幅指数 $\lceil 4) / 3) 」$, 歯列弓長指数 (1)/3)」, 雬列弓幅指数「2）/4)」, 菌列弓長幅指

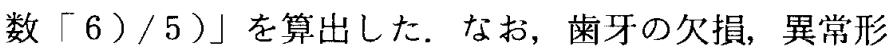
態など，計測に著しい誤差を生じると思われる模型は全 て除外した。 そのため菊列弓計測者は男性 36 名，女性 44 名であり, 生体計測者数よりかなり少ない数となっ た. 相関についても㐘列弓計測者について行なった。

\section{3 . 相関}

頭顔部の計測值と㐘列弓および山蓋高との間で相関係 数をもとめた．有意差の検定は $\mathrm{t}$ 検定により，危険率 $5 \%$ 以トで有意とし，表中に*印で表した。

\section{調査成績}

1. 頭顔部の計測値

頭顔部の計測成績はTable 1 に示すとおりである. これらのうち次の項月について Lebzelter-Saller $(1957)^{15)}$ の分類に従って検討した（Table 2，3）.

1 ）頭最大長

男性の平均值は $175.57 \mathrm{~mm}$, 女性の平均值は $168.41 \mathrm{~mm}$ で, ともに「短」型に属していた，頭長分 類型からみた各型の出現頻度をみると, 男性・女性とも に「短」型が最も多く，ついで「中」型であった。

2 ）頭最大幅

男性の平均值は $156.28 \mathrm{~mm}$, 女性の平均值は $151.28 \mathrm{~mm}$ で，男性・女性ともに「広」型に属してい た。頭幅分類型からみた各型の出現頻度をみると，男性 ·女性ともに「広」型が最も多く,ついで「中」型, 「過広」型の順であった。ただし男性では「広」型と 「中」型の差はほとんど認められなかった。

頭長と頭幅の分類型を組合せた各型の出現頻度をみる と，男性・女性ともに「短・㕕」型が最も多く，ついで 「短·中」型であった。

3 ）頬骨弓幅

男性の平均值は $139.94 \mathrm{~mm}$, 女性の平均值は $134.10 \mathrm{~mm}$ で，ともに「中」型に属していた．㚘骨弓 幅分類型からみた各型の出現頻度をみると，男性・女性 ともに「中」型が最も多く，ついで「広」型，「狭」型 の順であった。

4) 形態顔面高 
Table 1 Mean values of head and face measurements and difference of sex

$(\mathrm{mm})$

\begin{tabular}{lccr}
\hline \hline & Male & Female & Male-Female \\
& $\mathrm{M} \pm \mathrm{m}$ & $\mathrm{M} \pm \mathrm{m}$ & \multicolumn{1}{c}{$\mathrm{D} \pm \mathrm{m}$ diff. } \\
\hline Head length & $175.57 \pm 0.53$ & $168.41 \pm 0.47$ & $7.16 \pm 0.71^{* *}$ \\
Head breadth & $156.28 \pm 0.59$ & $151.28 \pm 0.53$ & $5.00 \pm 0.79^{* *}$ \\
Head height & $130.71 \pm 0.87$ & $127.37 \pm 0.65$ & $3.34 \pm 1.09^{* *}$ \\
Bizygomatic breadth & $139.94 \pm 0.64$ & $134.10 \pm 0.56$ & $5.84 \pm 0.85^{* *}$ \\
Bigonial breadth & $108.71 \pm 0.61$ & $103.16 \pm 0.68$ & $5.55 \pm 0.91^{* *}$ \\
Physiognomical facial height & $185.66 \pm 0.97$ & $181.11 \pm 1.16$ & $4.55 \pm 1.51^{* *}$ \\
Morphological facial height & $124.48 \pm 0.73$ & $118.54 \pm 0.57$ & $5.94 \pm 0.93^{* *}$ \\
Height & $1696.00 \pm 6.18$ & $1598.00 \pm 5.21$ & $98.00 \pm 8.08^{* *}$ \\
\hline & & $* *$ & Significantly different at the 0.01 level
\end{tabular}

Table 2 (a) Frequency of head breadth and head length classificational types (Male)

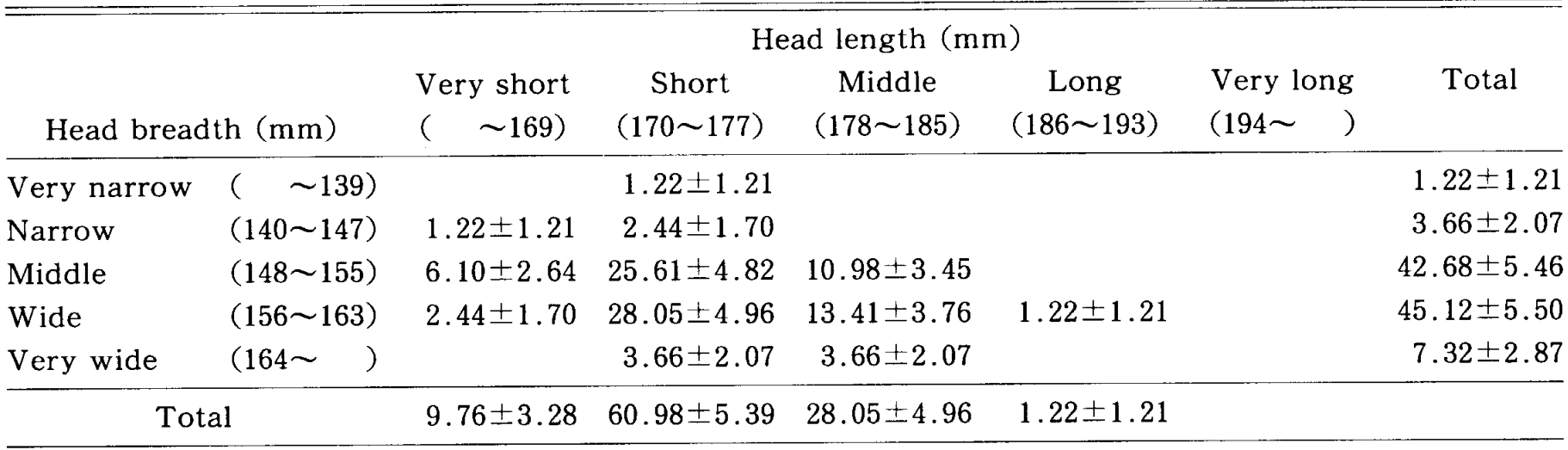

Table 2 (b) Frequency of head breadth and head length classificational types (Female)

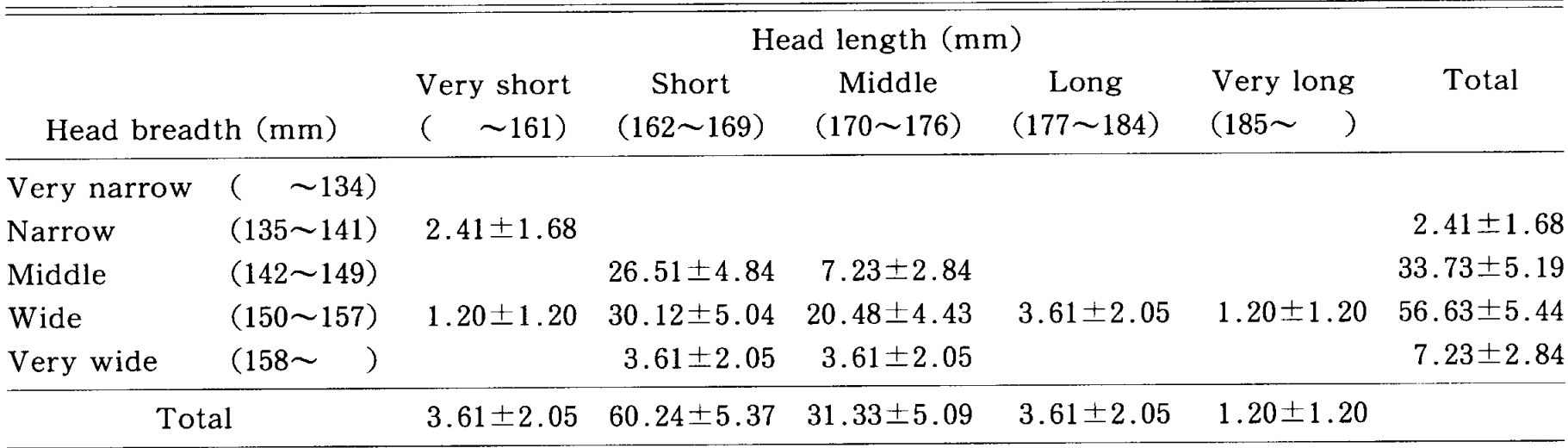

男性の平均値は $124.48 \mathrm{~mm}$, 女性の平均值は $118.54 \mathrm{~mm}$ で, ともに「高」型に属していた。形態顔 面高分類型からみた各型の出現頻度をみると，男性では 「中」型が最む多く, ついで「高」型,「過高」型の順, 女性では「過高」型,「高」型,「中」型の順であった。
峣員弓幅と形態顔面高の分類型を組合せた各型の出現頻 度をみると，男性では「中·高」型が最も多く，ついで 「中·中」型，「広·中」型，女性では「広·過高」型が 最む多く, ついで「中·過高」型，「中·高」型の順で あった. 
Table 3 (a) Frequency of Bizygomatic breadth and Morphological facial height classificational types (Male)

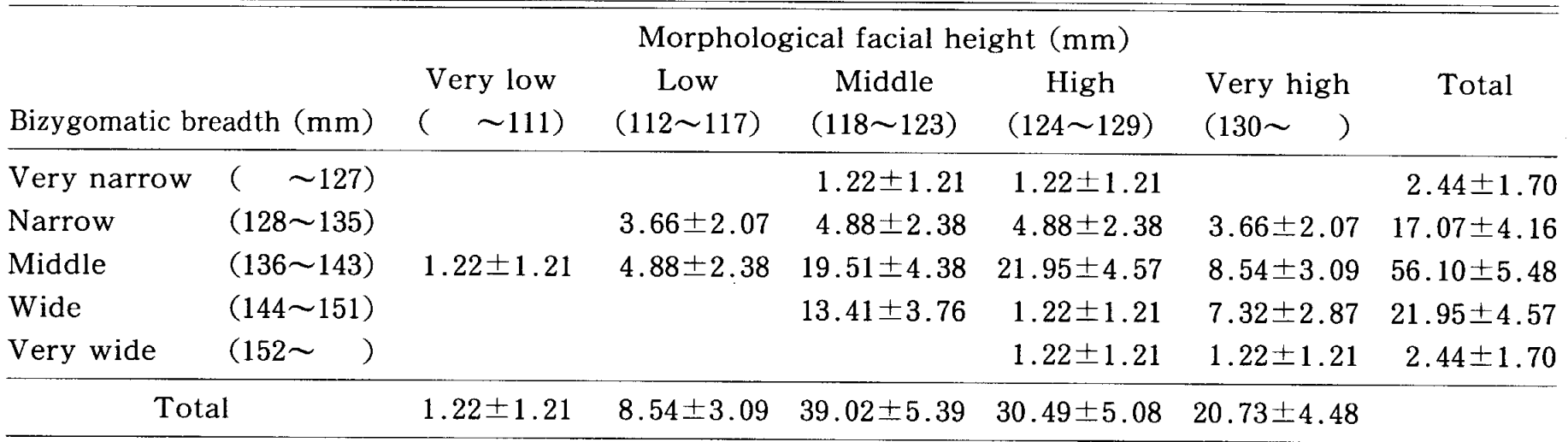

Table 3 (b) Frequency of Bizygomatic breadth and Morphological facial height classificational types (Female)

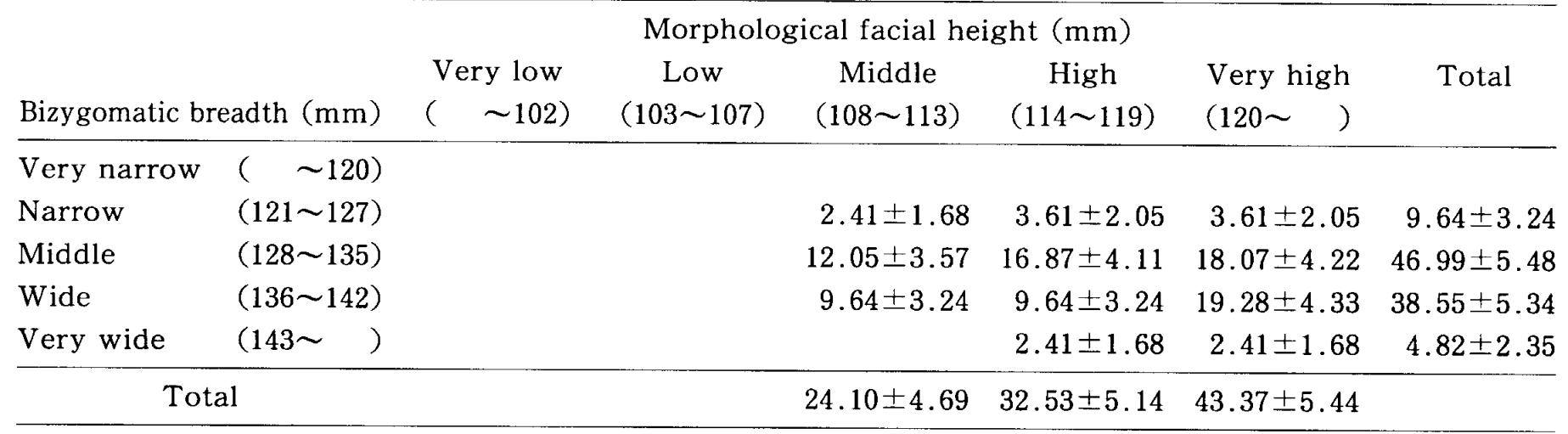

Table 4 Index of head and face measurements and difference of sex

\begin{tabular}{lccc}
\hline \hline & \multicolumn{1}{c}{$\begin{array}{c}\text { Male } \\
\mathrm{M} \pm \mathrm{m}\end{array}$} & $\begin{array}{c}\text { Female } \\
\mathrm{M} \pm \mathrm{m}\end{array}$ & $\begin{array}{c}\text { Male-Female } \\
\mathrm{D} \pm \mathrm{m} \text { diff. }\end{array}$ \\
\hline Cephalic index & $89.6 \pm 0.37$ & $89.86 \pm 0.34$ & $-0.80 \pm 0.50$ \\
Length-height index of head & $74.47 \pm 0.49$ & $75.66 \pm 0.39$ & $-1.19 \pm 0.63$ \\
Breadth-height index of head & $83.67 \pm 0.54$ & $84.25 \pm 0.46$ & $-0.58 \pm 0.71$ \\
Transversal cephalofacial index & $89.59 \pm 0.40$ & $88.67 \pm 0.32$ & $0.92 \pm 0.51$ \\
Physognomical facial index & $132.84 \pm 0.83$ & $135.19 \pm 0.96$ & $-2.35 \pm 1.27$ \\
Morphological facial index & $89.07 \pm 0.60$ & $88.50 \pm 0.51$ & $0.57 \pm 0.79$ \\
Jugomandibular index & $77.72 \pm 0.36$ & $76.97 \pm 0.48$ & $0.75 \pm 0.60$ \\
Vertical cephalofacial index & $95.46 \pm 0.65$ & $93.26 \pm 0.65$ & $2.20 \pm 0.92^{*}$ \\
\hline
\end{tabular}

* : Significantly different at the 0.05 level

頭顔部の計測值では，全ての項目で有意の性差を認 め，男性が女性より大であった。

2. 頭顔部の指数值

各指数の平均值は Table 4 に示すとおりであった.
計測值同様 Martin-Saller（1957 ${ }^{14)}$ の分類に従って, 次の項目について検討した。

\section{1) 頭長幅指数}

男性は 89.06, 女性は 89.86 で, 男性·女性ともに 
Table 5 Frequency of cephalic types

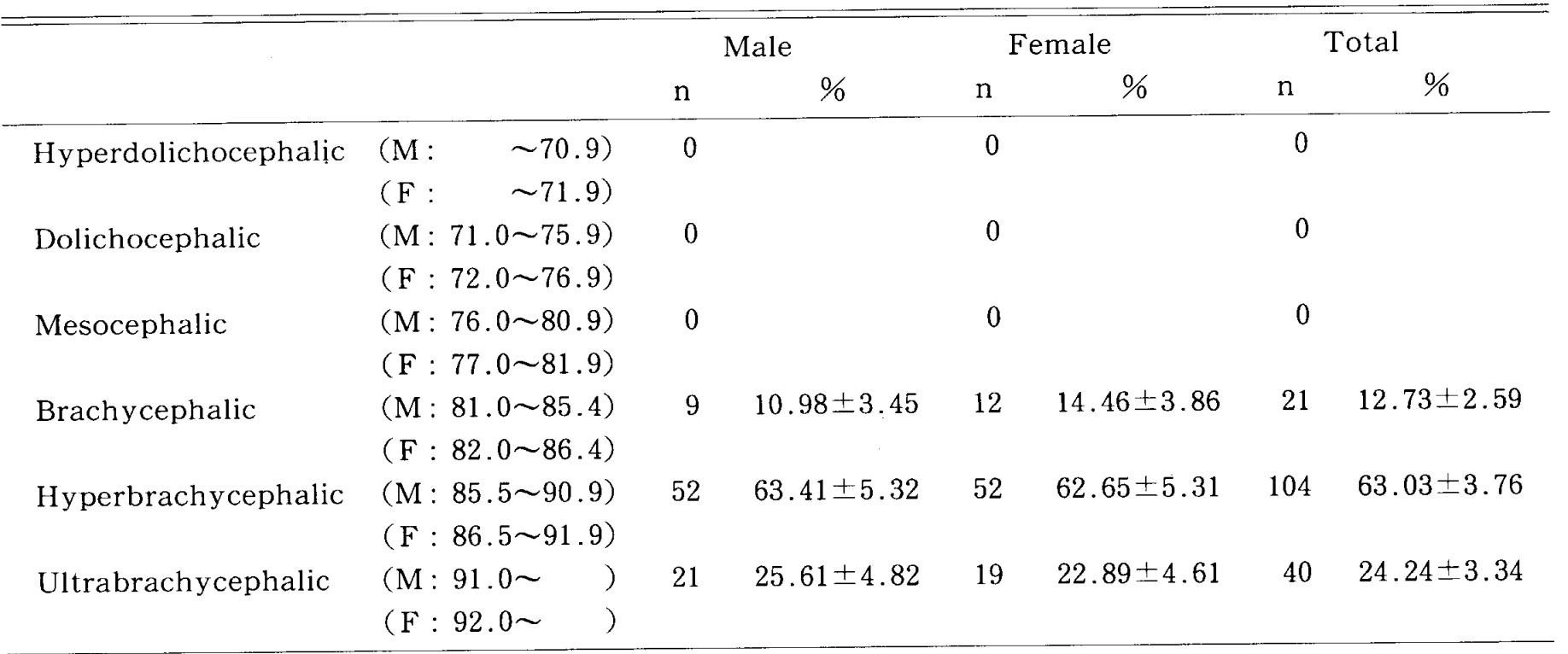

$\mathrm{M}$ : Male, F : Female

Table 6 Frequency of length-height types

\begin{tabular}{lccccccc}
\hline & & \multicolumn{2}{c}{ Male } & \multicolumn{2}{c}{ Female } & \multicolumn{2}{c}{ Total } \\
& & $\mathrm{n}$ & $\%$ & $\mathrm{n}$ & $\%$ & $\mathrm{n}$ & $\%$ \\
\hline Chamaecephalic & $(\sim \sim 57.9)$ & 0 & & 0 & & 0 & \\
Orthocephalic & $(58.0 \sim 62.9)$ & 0 & & 0 & & 0 & \\
Hypsicephalic & $(63.0 \sim 2)$ & 82 & 100 & 83 & 100 & 165 & 100 \\
\hline
\end{tabular}

Table 7 Frequency of breadth-height types

\begin{tabular}{lrrrrrrr}
\hline & & \multicolumn{2}{c}{ Male } & \multicolumn{2}{c}{ Female } & \multicolumn{2}{c}{ Total } \\
& & $\mathrm{n}$ & \multicolumn{1}{c}{$\%$} & $\mathrm{n}$ & $\%$ & $\mathrm{n}$ & $\%$ \\
\hline Tapeinocephalic & $(\quad \sim 78.9)$ & 14 & $17.07 \pm 4.16$ & 8 & $9.64 \pm 3.24$ & 22 & $13.33 \pm 2.65$ \\
Metriocephalic & $(79.0 \sim 84.9)$ & 34 & $41.46 \pm 5.44$ & 40 & $48.19 \pm 5.48$ & 74 & $44.85 \pm 3.87$ \\
Acrocephalic & $(85.0 \sim 2)$ & 34 & $41.46 \pm 5.44$ & 35 & $42.17 \pm 5.42$ & 69 & $41.82 \pm 3.84$ \\
\hline
\end{tabular}

「過短頭」型に属した．頭長幅指数の分類型よりみた出 現頻度でも, 男性・文性ともに「過短頭」型が最も多

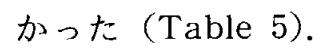

\section{2 ) 頭長高指数}

男性は74.47, 女性は75.66で, 男性・女性ともに 「高頭」型に属した．頭長高指数の分類型よりみた出現 頻度でも, 男性. 女性ともに全て「高頭」型であった (Table 6).

3 ) 頭幅高指数男性は 83.67 , 女性は 84.25 で, 男性
·女性ともに「中頭」型に属した．頭幅高指数の分類型 よりみた出現頻度では，男性は「中頭」型と「尖頭」型 が同数であり，女性は「中頭」型が最も多かった (Table 7).

\section{4) 形態顔面指数}

男性は89.07, 女性は88.50で, 男性・女性ともに 「狭顔」型に属した。形態顔面指数の分類型よりみた出 現頻度では, 男性は「狭顔」型, 女性は「超狭顔」型が 最も多かった (Table 8). 
Table 8 Frequency of morphological facial types

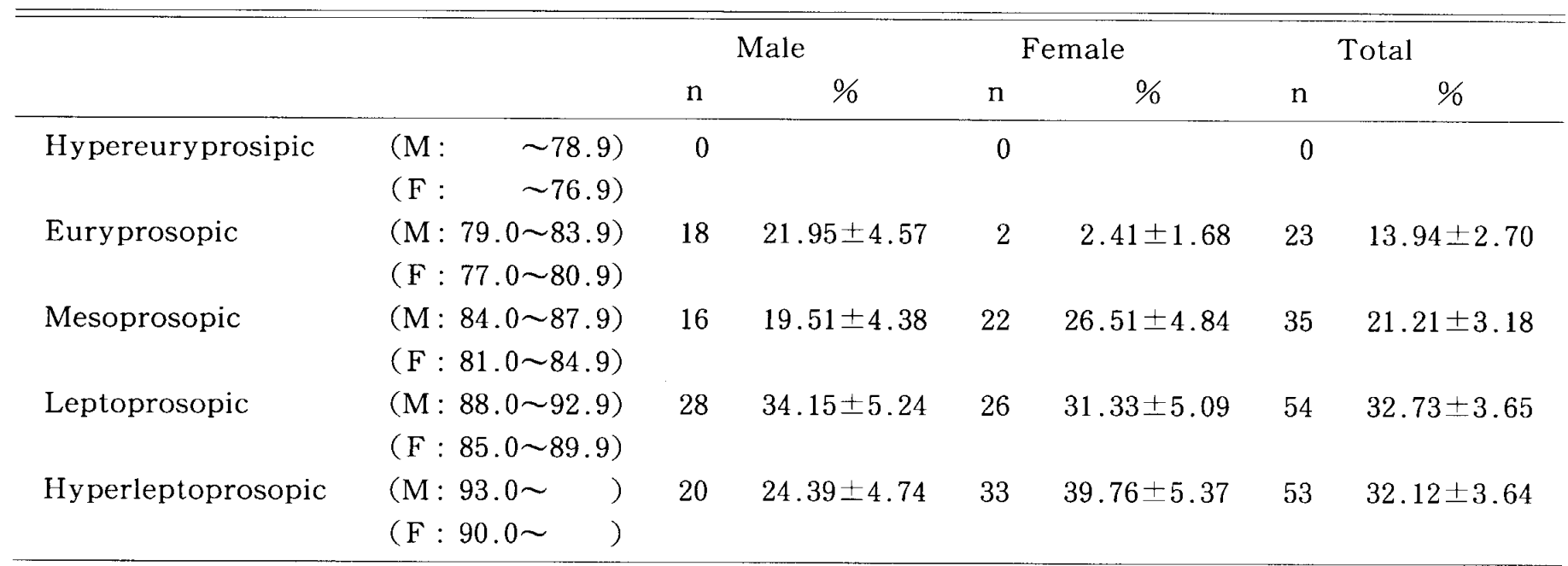

M: Male, F : Female

Table 9 Mean values of dental arch measurements and difference of sex

$(\mathrm{mm})$

\begin{tabular}{lccc}
\hline & $\begin{array}{c}\text { Male } \\
\mathrm{M} \pm \mathrm{m}\end{array}$ & $\begin{array}{c}\text { Female } \\
\mathrm{M} \pm \mathrm{m}\end{array}$ & $\begin{array}{c}\text { Male-Female } \\
\mathrm{D} \pm \mathrm{m} \text { diff. }\end{array}$ \\
\hline Upper jaw & & & \\
Ant. dent. arch length & $9.23 \pm 0.28$ & $8.80 \pm 0.20$ & $0.43 \pm 0.34$ \\
Post. dent. arch length & $39.16 \pm 0.47$ & $38.39 \pm 0.31$ & $0.77 \pm 0.56$ \\
Dent. arch length & $47.31 \pm 0.51$ & $45.70 \pm 0.34$ & $1.61 \pm 0.61^{*}$ \\
Ant. dent. arch breadth & $34.72 \pm 0.27$ & $33.32 \pm 0.37$ & $1.40 \pm 0.46^{* *}$ \\
Post. dent. arch breadth & $59.32 \pm 0.48$ & $57.54 \pm 0.43$ & $1.78 \pm 0.64^{*}$ \\
Dent. arch breadth & $54.17 \pm 0.46$ & $52.35 \pm 0.37$ & $1.82 \pm 0.59^{* *}$ \\
Palate hight & $14.23 \pm 0.38$ & $13.94 \pm 0.26$ & $0.29 \pm 0.46$ \\
\hline Lower jaw & & & \\
Ant. dent. arch length & $5.20 \pm 0.22$ & $5.12 \pm 0.17$ & $0.08 \pm 0.28$ \\
Post. dent. arch length & $34.41 \pm 0.40$ & $33.44 \pm 0.35$ & $0.97 \pm 0.53$ \\
Dent. arch length & $42.79 \pm 0.51$ & $41.67 \pm 0.42$ & $1.12 \pm 0.66$ \\
Ant. dent. arch breadth & $25.41 \pm 0.24$ & $25.24 \pm 0.32$ & $0.17 \pm 0.47$ \\
Post. dent. arch breadth & $51.00 \pm 0.43$ & $50.20 \pm 0.39$ & $0.80 \pm 0.58$ \\
Dent. arch breadth & $48.30 \pm 0.37$ & $46.90 \pm 0.33$ & $1.40 \pm 0.50^{*}$ \\
\hline
\end{tabular}

${ }^{*},{ }^{* *}$ : Significantly different at the 0.05 and 0.01 level

\section{頭顔部の指数值で性差が認められたのは鉛直頭顔指数} のみであり，男性の方が大であった。

3. 歯列弓の計測値および指数值

㐘列弓の計測值および指数值は Table 9,10 に示す とおりであった．計測值で有意の性差を示したのは, 上 罘では, 前歯列弓幅, 後蒾列弓幅, 歯列弓長および歯列 弓幅，下顎では歯列弓幅であり，いずれも男性の方が大
であった。

4. 頭顔部之柬列弓との相関

頭顔部の計測值 7 項目と歯列弓の計測值 5 項目との相 関係数を求め, Table 11 に示した.

有意な正の相関を認めた項目は次の通りである.

高径相互間の相関：男性で頭耳高と口蓋高および形態 顔面高と口蓋高との間, 女性では容貌顔面高と口蓋高と 
Table 10 Mean values of dental arch index and difference of sex

$(\mathrm{mm})$

\begin{tabular}{lrrr}
\hline \hline & \multicolumn{1}{c}{$\begin{array}{c}\text { Male } \\
\mathrm{M} \pm \mathrm{m}\end{array}$} & \multicolumn{1}{c}{$\begin{array}{c}\text { Female } \\
\mathrm{M} \pm \mathrm{m}\end{array}$} & $\begin{array}{c}\text { Male-Female } \\
\mathrm{D} \pm \mathrm{m} \text { diff. }\end{array}$ \\
\cline { 2 - 4 } & & & \\
Upper jaw & $388.22 \pm 12.03$ & $386.80 \pm 9.38$ & $1.42 \pm 15.25$ \\
Ant. dent. arch index & $152.31 \pm 2.31$ & $150.17 \pm 1.39$ & $2.14 \pm 2.70$ \\
Post. dent. arch length-beadth index & $23.46 \pm 0.53$ & $22.84 \pm 0.40$ & $0.62 \pm 0.66$ \\
Dental arch length-index & $58.61 \pm 0.50$ & $58.03 \pm 0.74$ & $0.58 \pm 0.89$ \\
Dental arch breadth index & $114.99 \pm 1.62$ & $114.77 \pm 1.03$ & $0.22 \pm 1.92$ \\
Dental arch index & & & \\
\hline Lower jaw & $518.36 \pm 20.59$ & $516.64 \pm 17.42$ & $1.72 \pm 26.97$ \\
Ant. dent. arch index & $148.96 \pm 2.26$ & $150.68 \pm 1.69$ & $-1.72 \pm 2.82$ \\
Post. dent. arch length-beadth index & $15.03 \pm 0.58$ & $15.23 \pm 0.44$ & $-0.20 \pm 0.73$ \\
Dental arch length index & $49.91 \pm 0.54$ & $50.37 \pm 0.67$ & $-0.46 \pm 0.86$ \\
Dental arch breadth index & $113.57 \pm 1.88$ & $112.88 \pm 1.10$ & $0.69 \pm 2.18$ \\
Dental arch index & &
\end{tabular}

Table 11 Correlation of mesurements between head-face and dental arch

\begin{tabular}{lccccc}
\hline \hline & $\begin{array}{c}\text { Upper dental } \\
\text { arch length }\end{array}$ & $\begin{array}{c}\text { Upper dental } \\
\text { arch breadth }\end{array}$ & Palate height & $\begin{array}{c}\text { Lower dental } \\
\text { arch length }\end{array}$ & $\begin{array}{c}\text { Lower dental } \\
\text { arch breadth }\end{array}$ \\
\multicolumn{1}{c}{ Male } & & & & & \\
Head length & 0.136 & 0.256 & 0.271 & 0.104 & 0.052 \\
Head breadth & 0.124 & 0.241 & 0.246 & -0.043 & 0.256 \\
Head height & 0.257 & 0.063 & $0.512^{*}$ & 0.106 & 0.034 \\
Physiognomical facial height & -0.034 & 0.288 & 0.090 & -0.250 & 0.100 \\
Morphological facial height & 0.254 & 0.127 & $0.570^{*}$ & 0.273 & 0.004 \\
Bizygomatic breadth & 0.143 & 0.184 & 0.169 & 0.133 & 0.091 \\
Bigonial breadth & -0.035 & 0.238 & 0.033 & -0.087 & 0.230 \\
\hline \multicolumn{1}{c}{ Female } & & & & & \\
Head length & -0.221 & 0.121 & 0.181 & -0.003 & 0.124 \\
Head breadth & -0.103 & $0.339^{*}$ & 0.217 & -0.111 & 0.283 \\
Head height & 0.148 & 0.115 & -0.067 & 0.094 & -0.020 \\
Physiognomical facial height & 0.277 & $0.344^{*}$ & $0.387^{*}$ & 0.164 & 0.269 \\
Morphological facial height & 0.072 & 0.194 & 0.184 & 0.223 & 0.236 \\
Bizygomatic breadth & -0.046 & $0.383^{*}$ & 0.004 & -0.038 & 0.295 \\
Bigonial breadth & 0.099 & 0.229 & 0.100 & 0.024 & 0.115 \\
\hline
\end{tabular}

* : Significantly different at the 0.05 level

の間.

幅径相互間の相関 : 女性の頭幅と上歯列弓幅および煩 骨弓幅之上歯列弓幅之の間.

高径之幅径間の相関 : 女性の容貌顔面高之上歯列弓幅 との間.

\section{考察}

中華人民共和国内における満族の 1990 年 7 月現在の 人口は, $9,821,180$ 人で, 東北三省 (遼寧省·吉林省 $\cdot$ 黒竜江省）を中心に，都市で他の民族と共に生活するも 


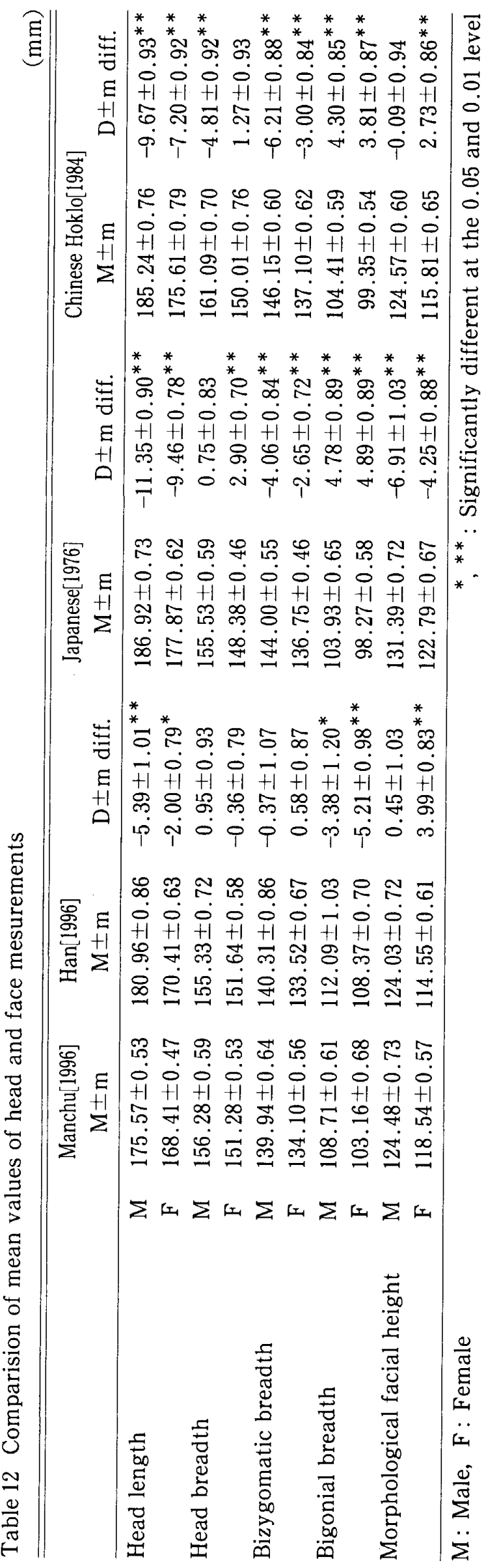

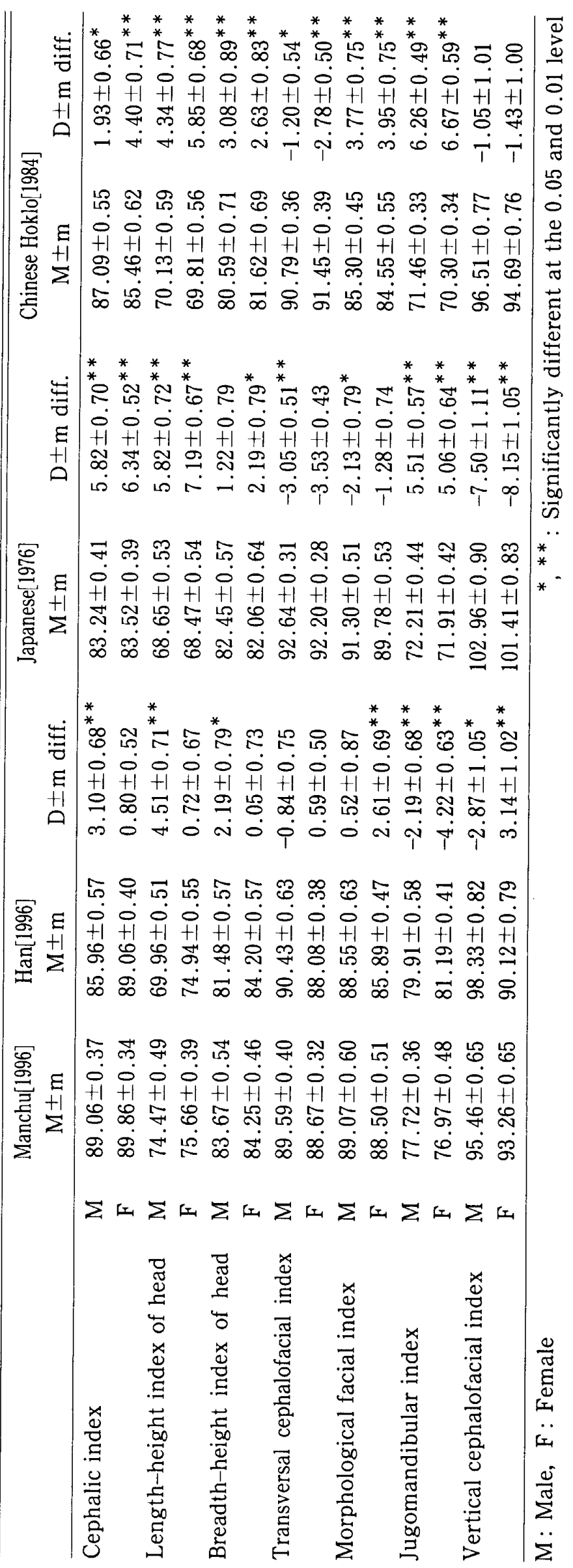


Table 14 Comparision of mean values and index of head and face measurements

\begin{tabular}{lccc}
\hline & $\begin{array}{c}\text { Manchu[1996] } \\
\text { Feng Cheng } \\
\text { M } \pm \mathrm{m}\end{array}$ & $\begin{array}{c}\text { Manchu[1937] } \\
\text { Hu Lan } \\
\text { M } \pm \mathrm{m}\end{array}$ & $\begin{array}{c}\text { Feng Cheng-Hu Lan } \\
\mathrm{D} \pm \mathrm{m} \mathrm{diff.}\end{array}$ \\
\hline Head length & $175.57 \pm 0.53$ & $183.75 \pm 0.57$ & $-8.18 \pm 0.78^{* *}$ \\
Head breadth & $156.28 \pm 0.59$ & $158.50 \pm 0.56$ & $-2.22 \pm 0.81^{*}$ \\
Bizygomatic breadth & $139.94 \pm 0.64$ & $144.76 \pm 0.48$ & $-4.82 \pm 0.80^{* *}$ \\
Morphological face height & $124.48 \pm 0.73$ & $124.68 \pm 0.63$ & $-0.20 \pm 0.96$ \\
Cephalic index & $89.06 \pm 0.37$ & $86.41 \pm 0.33$ & $2.65 \pm 0.50^{* *}$ \\
Length-height index of head & $74.47 \pm 0.49$ & $67.46 \pm 0.34$ & $7.01 \pm 0.60^{* *}$ \\
Breadth-height index of head & $83.67 \pm 0.54$ & $78.21 \pm 0.40$ & $5.46 \pm 0.67^{* *}$ \\
Transversal cephalofacial index & $89.59 \pm 0.40$ & $91.34 \pm 0.27$ & $-1.75 \pm 0.48^{* *}$ \\
Morphological facial index & $89.07 \pm 0.60$ & $86.28 \pm 0.44$ & $2.79 \pm 0.74^{* *}$
\end{tabular}

${ }^{*},{ }^{*}$ : Significantly different at the 0.05 and 0.01 level

のと，地方で独自の集落を形成するものとがある．著者 の調査した鳳城市は住民のほとんどが満族であり，後者 の発展したものといえる。また同地域で頭顔部と㐘列尸 を同時にみた報告は伊東ら $(1996)^{5)}$ が漢族について 行っている以外は見受けられない，今村ら $(1954)^{17)}$, 竹野ら (1966) ${ }^{18)}$ は頭顔部の形態について, 年齢差は地 方差よりあ大きく，かつ年代差は年齢差よりも大きいと 報告している．そこで著者は同地域に居住する満族を調 査するとともに先人の報告と比較した.

\section{1. 頭顔部の計测值および指数值}

頭顔部の計測值掞よび指数値を，伊東ら5の遼寧省漢 族, 大森ら $(1985)^{12)}$ の福建系台湾人, 加藤 $(1977)^{11)}$ の九州日本人と比較し (Table 12,13), さらに令村ら (1946) $)^{1)}$ の呼蘭満族と比較検討した (Table 14).

\section{1 ) 頭顔部の計測值}

頭最人長は男性·女性ともに漢族, 福建系台湾人扰よ び九州日本人より有意に小さい值を示した。

頭最大幅は男性では福建系台湾人より有意に小さく， 女性では九州日本人より有意に大きい值を示した。

頬骨局幅は男性・姓ともに福建系台湾人および九州 日本人より有意に小さい値を示した。

下罠角角幅は男性・女性ともに福建系台湾人，九州日本 人より有意に大きく，漢族より有意に小さい值を示し た.

形態顔面高は男性では九州日本人より有意に小さい値 を示した，女性では漢族执よび福建系台湾人より有意に 大きく，九州日本人より有意に小さい値を示した。

2 ) 頭顔部の指数值
頭长幅指数は男性では漢族, 福建系台湾人および九州 日本人より有意に大きい值を示した，女性では福建系台 湾人抢よび九州日本人より有意に大きい值を示した。

頭長高指数は男性では有意に漢族, 福建系台湾人およ び九州日本人より大きい值を示した，女性では福建系台 湾人抢よび九州日本人ょり有意に大きい值を示した。

頭幅高指数は男性では有意に漢族および福建系台湾人 より大きい值を示した，女性では福建系台湾人および九 州の本人より有意に大きい值を示した。

形態顔面指数は男性では九州日本人より有意に小さ く, 福建系台湾人より有意に大きい值を示した，女性で は漢族抢よび九州日本人ょり有意に小さい值を示した。

次に今村" の呼蘭の成績と比較してみる。呼蘭は黒竜 江省にあり，著者の調查した鳳城よりかなり北に位置す る.また年代的には約 60 年の隔たりがある. 計测值で 有意の差がみられたのは, 頭最大長, 頭最大幅および蝢 骨马幅でいずれも著者の成績の方が小さい，指数值で は, 頭長幅指数, 頭長高指数, 頭幅高指数㧍よび形態顔 面指数は有意に著者の成績が大きく，鉛直頭顔指数は有 意に著者の成績が小さい。

頭部の形態は大森ら ${ }^{12}$, 加藤"1らあ述べているごとく, 時代とともに頭最大長は徐々に短くなり，頭最大幅はや や広がり, 全体として短頭化を示す. 著者の結果は福建 系台湾人，九州日本人，漢族ならびに呼闌の満族よりも 短頭であった。これは満族の特徴であるとともに，地域 差というよりあ年代的に着実な短頭化が進んでいるため と思われる.

顔面の形態について大森ら ${ }^{22}$ は福建系台湾人の顔面は 
上部の幅が広く，ト部が狭くなっておう，逆僧帽型に近 い顔面形態が代表をなすと述べている。これは加藤 (1977) "1) の九州日本人の形態ともよく似ている。しか しながら著者の結果は全く逆で, 上部の幅が狭く，下部 が広くなっており，全体として方形に近い。これは漢族 の形態とほぼ同様であった。

\section{2. 頭顔部之歯列弓およびロ蓋高との相関}

頭顔部之㐘列弓との相関に関して, 邦人についての報 告をみると，酒井 $(1955)^{8)}$ は頭型と上下顎抢よび口蓋 形との間に相関は認めないが, 顔型と下顎歯列弓形およ び口蓋形の間には，かなりの相関を認めると述べてい る. 浜田 $(1965)^{9)}$ は歯列弓幅径と顔面計測值との相関 が，より強いと述べている. 南 $(1976)^{10)} や$ 加藤 11 は幅 径相互間に著明な正の相関を認めるが，長径相互間，長 径と高径問では相関を認めずまた，頭部より顔面部にお いて比較的強い正の相関を䜑めると述べている．また台 湾人について呂 $(1960)^{19)}$ は㚘具弓幅と上歯列弓幅との 間で，男性·女性ともに $30 \sim 50 \%$ 正の相関を認める が，他の項目間ではこれを全く認めないと述べている。

一方, 大森ら $(1985)^{12)}$ は吕 ${ }^{19)}$ と比較し, 顔面之菡列弓 之の間には男性·女性と屯いくつかの項目で相関を認め るが, 㚘面骨弓幅之上歯列弓幅との間では男性·女性と屯 相関を認めないと述べている.

これら先人の報告から，しばしば正の相関が認められ るのは规骨弓幅と上歯列弓幅, 下顎角幅と下歯列弓幅, 形態顔面高あるいは容貌顔面高と口蓋高との間である. これらの報告と本研究の結果を比較すると，男性におい ては頭耳高と口蓋高との問で有意な正の相関を認め, 煩 骨弓幅之上歯列弓幅, 下顎角幅と下歯列弓幅との間では 有意な相関は認めない. 一方, 女性においては頭最大幅 および容貌顔面高と上歯列弓幅との間で有意な正の相関 を認め, 下顎角幅と下歯列弓幅との間で有意な相関は認 められない.これらの結果は満族の特徵であると考えら れる。

\section{結 論}

1995 年 8 月～9 月中華人民共和国遼寧省鳳城市にお いて満族の男性 82 名, 女性 83 名の生体計測ならびに歯 列印象模型より㐘列弓の計測を行った。さらに頭顔部

(頭最大長, 頭最大幅, 頭耳高, 㚘員弓幅, 下顎角幅, 容貌顔面高, 形態顔面高) と蒾列弓（上歯列弓長, 上歯 列弓幅, 下歯列弓長, 下歯列弓幅）および凸莣高との相 関関係についても調査し，つぎの結論を得た。

1. 頭最大長：男性の平均值は $175.6 \mathrm{~mm}$, 女性の平
均值は $168.4 \mathrm{~mm}$ で, 男性·女性と屯に「短」型で, 男 性・女性ともに漢族, 福建系台湾人扰よび九州日本人よ り有意に小さい值を示した。

2. 頭最大幅：男性の平均值は $156.3 \mathrm{~mm}$ ，女性の平 均值は $151.3 \mathrm{~mm}$ で, 男性·女性と屯に「㕕」型で, 男 性では福建系台湾人より有意に小さく，女性では九州日 本人より有意に大きい值を示した.

3. 煩骨弓幅: 男性の平均値は $139.9 \mathrm{~mm}$, 女性の平 均值は $134.1 \mathrm{~mm}$ で, ともに「中」型で, 男性・姓と あに福建系台湾人おょび九州日本人ょり有意に小さい值 を示した。

4. 形態顔面高：男性の平均值は $124.5 \mathrm{~mm}$, 女性の 平均值は $118.5 \mathrm{~mm}$ で, ともに「高」型で, 男性では 九州日本人より有意に小さい值を示した，女性では漢族 扮よび福建系台湾人上り有意に大きく，九州日本人より 有意に小さい值を示した。

5。満族の頭顔部の形状は「過短頭」型で，男性では 漢族，福建系台湾人および九州日本人より有意に大きい 值を示した，女性では福建系台湾人および九州日本人上 り有意に大きい值を示した。

6. 形態顔面指数は「狭顔」型で，男性は九州日本人 より有意に小さく，福建系台湾人より有意に大きい值を 示した。㚣性では漢族および九州日本人より有意に小さ い值を示した。

7。頭顔部之菌列弓との相関は男性では頭耳高および 形態顔面高と口蓋高との間, 女性では頭最大幅, 煩骨弓 高および容貌顔面高と上歯列弓幅との間, 容貌顔面高之 口蓋高との間に正の相関を認めた。

稿を終わるにあたり，終始ご懇切なるご指導とご校閲 を睗った小林繁教授に深芫なる感謝の意を捧げます。ま たご協力いただいた伊東励講師ならびに口腔解剖学教公 の各位に感謝いたします。資料蒐集にあたって，ご協力 いただいた瀋陽医学院の解剖教研室の富成志教授はじめ 教室員の皆様に心より厚く御礼申し上げます。

\section{引用文献}

1) 今村 豊, 島 五郎: 北満諸民族の體質人類学. 日本人及 び近接諎民族の人類学 2 , 人類学先史学講座 4. 雄山 閣, 東京, 1940, 192-237.

2) 横尾安夫: 蒙古人. 日本人及び近接諸民族の人類学 2 , 人類学先史学講座 4. 雄山閣, 東京, 1940, 238-269.

3) 矢吹正吾: 蒙古人歯列引に関する生物学的研究. 日本口科 学会雑誌 $35: 267-318,1942$.

4) 荷宮文夫: 咬合之㐘弓の民族科学的研究. 柬科学雑誌 
5(4) : 102-107, 1948.

5）伊東 励, 金 晧, 久保博英, 金子政則, 小林 慗, 富 成志, 張 庭深, 王 文奎：遼眇省漢族の頭顔部および歯 列弓の形態に関する研究. 九州米会誌 50:947-956, 1996.

6）大島新平：歯列の形態についての研究（その4）顔面頭蓋 及び脳頭蓋との関係. 満州医誌 $25: 43-46,1936$.

7) 深沢龍之助：顔面之雪列の関係に関する変異統計学的研 究. 慶応歯科 2:101-126, 1941 .

8 ）酒井琢朗：頭顔部歯列弓口蓋との形状ならびに大きさの相 関関係. 信州医誌 4:291-294，1955.

9 ）浜出貞雄：柬列弓諸測度と身体諸测度との間の相関に関す る研究. 日大茵学 39 ：455-462, 1965.

10）南 幸夫：長崎県南松浦郡五島三井楽町仿民における頭顔 部の生体計測ならびに菌列弓との相関について，九州蒾会 誌 $30: 152-169,1976$.

11）加藤喜陸：長䗁県壱岐勝本住民における頭顔部の生体計測 ならびに菊列弓との相関について，九州曾会誌 $30: 976-$ 988, 1977.

12）大森忠雄, 藤 英俊, 浜忛法康, 中村隆之, 武井俊哉, 魏
賢治，哭 啓成，羅 珵玲：福建系台湾人の頭・顔面部お よび歯列弓の形態に関する研究. 歯基礎誌 $27: 27-38$, 1985.

13）内田雄康：台湾 A tayal 族の頭 - 顔面部の形質人類学的研 究. 九州蒾会誌 $41: 916936,1987$.

14）毛利達雄：台湾原住民 Saisiyat 族の歯列弓および頭・顔 面部に関する研究. 九州歯会誌 41：937-959，1987.

15) Martin, R. and Saller, K.: Lehrbuch der Anthropologie, 3 Lieferung, Gustav Fischer Verlag, Stuttgart, 1957, 362-386.

16）山浦俊一：日本人 (長野県) の㐘列弓, 口蓋の形態学的研 究 1. 菌列弓の大きさ。柬科学報 $70: 1106-1128$, 1970.

17）今村 豊: 形質人類学の一問題. 人類誌 $63: 100-102$, 1954.

18）竹野文明, 居川忠夫：種子岛住民の生体計測学的研究. 鹿 大医誌 $18 ： 559-578,1966$.

19）谷 清寛：台湾人諸種族の蒾列弓形態並びにそれと頭部及 び顔面各部之の相関. 人類学研究 $7: 454-492,1960$. 